\title{
モーニング手術手技セミナー(6) 中耳手術
}

\author{
経外耳道的内視鏡下耳科手術（TEES）の基本手技 \\ 伊藤 吏 \\ 山形大学 医学部 耳鼻咽喉・頭頸部外科
}

【はじめに】

硬性内視鏡に付随するビデオシステムの高精細（high definition：HD）化に伴い、すべての行程を内視鏡下に行う経 外耳道的内視鏡下耳科手術（transcanal endoscopic ear surgery：TEES）が広く行われるようになっている。TEESで は広角な視野により一視野で鼓室の全体像を把握することが可能であり、さらに内視鏡の接近による拡大視や斜視鏡の 使用により死角の少ない手術操作が可能となる。このような利点をもつ TEES は耳後切開不要の低侵襲手術であるが、 経外耳道的な keyhole surgery であり、原則 one-handed surgery という課題もある。本セミナーではこのような課題 に対応しながら TEES の利点を十分に発揮するためのセットアップや手術手技などについて手術ビデオを供覧しながら 解説する。

【TEES のセットアップ】

当科では直径 $2.7 \mathrm{~mm}$ 、有効長 $18 \mathrm{~cm} 、 0$ 度、30度の硬性鏡に Full HD の 3CCD カメラとモニターを組み合わせて TEES を施行している。上鼓室や乳突洞病変への操作が必要な場合には、洗浄と吸引を兼ね備えた超音波骨削開器や力 ーブバーを用いた transcanal attico-antrostomy を行い、最小限の骨削開で乳突洞までアプローチを行う Powered TEES を行っている。耳鼻咽喉科で使用される内視鏡には太さや長さのバリエーションがあるが、直径 $2.7 \mathrm{~mm}$ の内視鏡を用 いることで外耳道径の小さい小児症例でも手術が可能であり、有効長 $18 \mathrm{~cm}$ の内視鏡で powered device を操作するス ペースも確保できる。また、LED 光源を用いることで観察部位や鏡筒の温度上昇による組織障害を予防できる。

TEES では安定した内視鏡の保持を行うための左腕用肘置きが必須である。また不測の事態に備えて顕微鏡は常時ス タンバイとする。はじめにきれいな視野を確保するために、外耳道の清掃と耳毛の処理を行う。耳后および耳毛を丹念 に清掃、除去することで、内視鏡の出し入れの際に先端が污れることを予防する。さらには耳珠を前方に衰引固定する とともに耳介裏面にたたみガーゼをおいて耳介を外側後方にテープで牽引固定し、軟骨部外耳道を直線化することで内 視鏡の出し入れが容易となり、結果的に手術時間の短縮化につながる。

\section{【手術手技の工夫】}

内視鏡のブレを防ぐため、術者は脇をしめ、肘を手台にのせて支点とし、さらに内視鏡先端を軟骨部外耳道に固定し て視野を確保する。前鼓室や後鼓室、上鼓室や乳突洞など、観察する方向や操作する方向に従って内視鏡や手術機器の 挿入角度の調整が必要となるが、術者がなるべく自然な姿勢で手術操作ができるようにベッドのローテーションもその 都度組み合わせる。曇り止め対策として、最り止め成分付スポンジであるドクターフォグミに晨り止め液剤であるウル トラストップ®を滴下したものを用いて、内視鏡を耳内から出す度に助手が先端をふいている。この操作は、硬性鏡先 端を冷却する効果も期待できる。

tympanomeatal flap 挙上の際は出血予防と液性剥離の効果を期待して、外耳道皮下に30万倍エピネフリン入り0.5\% リドカインを、注射針先端を外耳道骨面にあてながら緩徐に剥離するように注射する。外耳道皮膚の弧状切開は、骨部 外耳道の中間の深さを基準とするが、attico-antrostomy を予定しているときは外側の骨部外耳道と軟骨部外耳道の境界

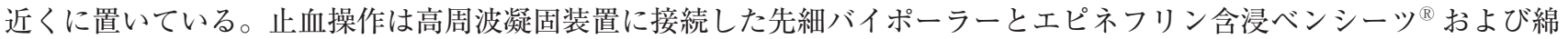
球を用いて行う。また、原則として片手操作となる TEESでは、ベンシーツや綿球を tympanomeatal flap を眽転固定す るための左手代わりに用いたり、出血部位の圧迫に用いたりすることで片手操作の弱点を補うことができる。

セミナーでは耳鼻咽喉科医師が TEES を導入するにあたり TEES の良い適応となる慢性穿孔性中耳炎や中耳奇形症例 を中心に、手術ビデオを供覧しながら TEES の基本手技について解説する。 


\title{
中耳手術＜顕微鏡下＞
}

\author{
山本裕 \\ 東京慈恵会医科大学 耳鼻咽喉科
}

側頭骨という硬組織の内部の含気腔である中耳腔を操作する中耳手術では、一般の外科基本手技とは異なる特殊な操 作を要する。本セミナーでは安全・確実に中耳手術を行う上での留意点を耳後部切開、顕微鏡下での手術を想定して概 説する。

1. 準備

手洗いの前に手術室全体を見渡して手術の環境を整える。手術台、各種機器、無影灯の最適な位置関係を構築する。 顕微鏡、録画システム、画像モニターの設定など可能なことは麻酔導入中に済ませておく。

麻酔導入後、術側を最終確認した後に適切な体位をとる。頭部の長軸が水平になるように、また側頭骨の坦面が術者 の視軸に垂直になるように調整する。 $\mathrm{NIM}^{\circledR}$ を用いる場合は、適切な針電極の刺入、脱落防止に配慮するとともにイン ピーダンスが適切かを確認する。

手洗い消毒の後、美しいシーツ掛けを行う。十分な術野が確保されるよう、頭髪がはみ出ないように十分配慮する。

2. 術野の作成、展開

皮切は施行したい手術の術野の展開に必要十分なものでなければならない。骨膜の切開と剥離挙上も術式に応じて十 分な範囲で行う。骨膜弁が挙上され、側頭骨外側が露出した時点で再度術野の空間軸を確認してから次の操作に移る。

3. 手術手技総論

(1) 剥離

外耳道皮膚、鼓膜、真珠腫上皮、肉芽などの剥離は中耳手術で最も基本的な操作だが、剥離するレイヤーによって操 作は異なる。骨組織から粘膜、骨膜ごと剥離する場合は器具が骨面に直接あたるように操作する。一方、粘膜、骨膜な どの軟部組織を深部に残して剥離を行う場合は、剥離面を強拡大でよく観察しながらソフトタッチで剥離を行う。しか

し癒着が強く剥離が困難な場合は、マイクロメスなどを用いて鋭的に切離することも必要となる。

(2) ドリリング

ドリルは基本的にペンホルダーで持つが、ぶれないように手首や前腕を術野に固定する。バーはドリリングの序盤で はなるべく大きいものを用いて染部に行くにしたがってサイズを適時小さくしていく。カッティングバーとダイアモン ドバーの特性の違いをよく理解して、適切に使い分ける。また温度上昇による組織障害やバーの目詰まりの防止のため に十分なイリゲーションを行う。

(3) 吸引

顕微鏡下耳科手術のほとんどのフェイズで左手の操作は吸引管により行うことになる。穴のあるなしや太さの使い分 けを種々の場面で行う。大きいカッティングバーでドリリングを行っている場合には、太めの吸引管でイリゲーション を吸引しつつ、バーが逸脱して重要臓器にあたることがないように吸引管でプロテクトすることも重要となる。一方、 軟部組織を把持する場合は吸引により組織がちぎれないように極細の吸引管で穴を押さえずに使用するなど種々のテク ニックを身に着ける。

(4) 止血と洗浄

常に術野に出血がない状態を保ちながら手術を進行させたい。そのためには出血がみられるたびに洗浄と止血操作を 繰り返し行う。浅部の軟部組織の止血は電気メスで行うが、深部では顔面神経や内耳への障害を配慮する必要がある。 すぐに止血が得られない場合には深追いはせずエピエフリン液を浸したガーゼで圧迫してほかの操作をしながらしばし 待つという姿勢も重要である。骨面からの出血は骨蝋やダイアモンドバーによる研磨が有効である。

(5) Positive identification

硬組織である骨構造の中に重要臓器が潜んでいる中耳手術では、時に解剖学的な位置関係を失認することがある。そ の場合はダイアモンドバーで積極的に骨組織を薄くして、背後の組織を透見できるようにして位置関係を弱拡大で確認 するという姿勢も重要である。

4. 手術手技各論

(1) 顔面神経

膝部の外側、水平部、垂直部で露出が多く注意を要する。膝部では真珠腫の剥離を乳突洞から上鼓室に進める時に、 水平部ではアブミ骨周囲の操作時に、垂直部では外耳道後壁削除時に損傷しやすい。基本的な剥離操作は神経の走行に

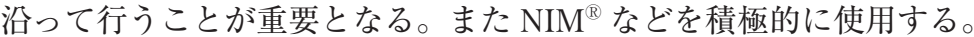

(2) 鼓索神経

鼓膜の挙上剥離時、scutumの削開時、ツチ骨骨頭の切除時に損傷しやすい。神経と軟部組織との剥離ではあえて鋭 的に操作を行い牽引を避けること、また乾燥を防止することにも留意する。

(3) 頭蓋窩、S 状静脈洞

サイズが小さいカッティングバーで一部のみが深くなるような削開を行ったときに損傷が起こりやすい。接近する前 に大きなダイアモンドバーを構造の走行に平行に動かしながら削開するように留意する。

(4) 耳小骨

連鎖が保たれている症例では、バーが接触しないように注意する。もし操作上心配がある場合には積極的に連鎖をは ずしてからドリリングを進める。アブミ骨周囲の病変除去時には、顔面神経水平部に注意しながら、操作の方向がなる ベく底板の長軸に沿った前方に向かうようにして底板の脱臼防止に配慮する。 